\title{
Bina Agarwal
}

\section{The Crisis}

When we were young we used to go to the forest early in the morning ... In a short while we would gather all the fodder and firewood we needed, rest under the shade of some huge tree and then go home. Now, with the going of the trees, everything else has gone too [A woman in the Uttarakhand hills, India (Bahuguna 1984:132)]

In the Himalayan foothills of Nepal, a journey to gather firewood and fodder took an hour or two a generation ago - today it takes the whole day [Eckholm 1975]. An observer notes: 'Nowhere can there be seen a tree or bush unscarred by axes, knives and browsing domestic animals. The imprint of people searching for fuel and fodder is to be seen everywhere' [Hughart 1979:28]. In Bihar, seven or eight years ago, women of poor rural households could get enough firewood for self-consumption and sale within one and a half to two $\mathrm{km}$ - they now trek eight to ten $\mathrm{km}$ per day [Bhaduri and Surin, 1980]. In some villages of Gujarat where the surrounding forests have been completely denuded, women spend long hours collecting weeds and shrubs and digging out the roots of trees. These do not provide continuous heat and increase cooking time [Nagbrahman and Sambrani 1983].

Fuel shortages are driving villagers in several regions of South Asia to shift to foods that require less fuel but are of lower nutritional value, or to miss some meals altogether and go hungry [Hughart 1979]. Necessity is also driving people in some areas to shift to food which can be eaten raw but is less nutritious, or to eat partially cooked food (which could be toxic), or to eat cold leftovers (with the danger of food rotting in a tropical climate). This is the human face of the crisis of cooking fuel shortages that is surfacing with growing urgency in rural South Asia.

Today we can no longer associate the problem of hunger only with food sufficiency - it is linked crucially to fuel sufficiency. As one observer aptly put it: 'Lack of fuel can be as much a cause of malnutrition as a lack of food' [Poulsen 1978]. This has for generations been part of the conventional wisdom of rural women who have said: 'It's not what's in the pot that worries you, but what's under it'. But it is a concern that has not permeated beyond rhetoric and piece-meal measures in the development planning of South Asia.

The crucial aspect that needs recognition is the threeway link between the cooking energy crisis, poverty and socioeconomic inequalities. This recognition is necessary not only for appropriately pinpointing the implications of the crisis and its complex causes, but also for understanding why most State-instituted treeplanting and other schemes launched ostensibly to alleviate the crisis have failed so dismally. This article seeks to explicate the link. In doing so it also posits the question: can we effectively deal with the cooking energy problem without any measures to reduce existing socioeconomic (especially land-based) inequalities, and without re-examining the development strategies adopted in South Asia?

Table 1 highlights the significance of woodfuel (woodbased fuel, essentially firewood and charcoal) as a source of inanimate energy in South Asia. Existing estimates suggest that much of this is consumed directly as firewood. If we take energy consumption by the rural domestic sector alone, the importance of firewood is greater still. In the hills and desert areas of Northern India, an estimated 67 and 65 per cent respectively of total domestic energy consumed by rural households is from this one source [NCAER 1981]; although the average for Northern India as a whole is lower - 42 per cent - and for Southern India it is 31 per cent (Table 2). Also, over 90 per cent of domestic energy is used for cooking and water heating in both regions. While the macro-surveys do not give cross-tabulations of the fuel source by end use, microstudies for India indicate that in large parts of the country firewood is the single most important cooking fuel - in some villages it provides 100 per cent of cooking energy. More ty pically, however, in India and in South Asia generally, firewood is supplemented by animal wastes and crop residues, the proportions varying according to the availability of different fuels to the household. Firewood is the preferred fuel and the substitution of firewood by inferior fuels such as paddy straw, dung or leaves and weeds, usually reflects the household's poor economic status. A Bangladesh field study shows a sharp decrease in the proportionate and absolute daily consumption of 


\begin{tabular}{|c|c|c|c|}
\hline Country & $\begin{array}{c}\text { Commercial energy } \\
\text { per capita } \\
\mathrm{kg} C E\end{array}$ & $\begin{array}{l}\text { Woodfuel consumption } \\
\text { per capita } \\
\mathrm{kg} C E\end{array}$ & $\begin{array}{c}\text { Woodfuel as a \% of } \\
\text { total energy } \\
\text { (Commercial and Woodfuel) }\end{array}$ \\
\hline Bangladesh & 49.8 & 108.5 & 68.5 \\
\hline India & 200.6 & 96.8 & 32.5 \\
\hline Nepal & 11.2 & 298.6 & 96.4 \\
\hline Pakistan & 225.8 & 68.7 & 23.3 \\
\hline Sri Lanka & 121.9 & 163.8 & 57.3 \\
\hline
\end{tabular}

Note: $\mathrm{CE}=$ coal equivalent

Source: Agarwal 1986a:8-9

\section{Table 2 Domestic fuel consumption per household by income class, fuel type and end-use in rural India}

\begin{tabular}{|c|c|c|c|c|c|c|c|c|c|}
\hline \multirow{2}{*}{$\begin{array}{l}\text { Income Class } \\
\text { Rs/annum }\end{array}$} & \multirow{2}{*}{$\begin{array}{c}\text { Total } \\
\text { domestic } \\
\text { energy }\end{array}$} & \multicolumn{4}{|c|}{ Type of fuel } & \multicolumn{4}{|c|}{ End use } \\
\hline & & $\begin{array}{l}\text { Fire- } \\
\text { wood }\end{array}$ & $\begin{array}{l}\text { Dung } \\
\text { Cakes }\end{array}$ & $\begin{array}{c}\text { Crop/ } \\
\text { Vegetable } \\
\text { Waste }\end{array}$ & $\begin{array}{l}\text { Char- } \\
\text { coal }\end{array}$ & Other & Cooking & $\begin{array}{l}\text { Water } \\
\text { heating* }\end{array}$ & Lighting \\
\hline $\begin{array}{l}\text { Northern India } \\
(1975-76)\end{array}$ & $\begin{array}{l}1315 \\
(100)\end{array}$ & $\begin{array}{l}551 \\
(42)\end{array}$ & $\begin{array}{l}312 \\
(24)\end{array}$ & $\begin{array}{l}382 \\
(29)\end{array}$ & $\begin{array}{c}8 \\
(1)\end{array}$ & $\begin{array}{l}62 \\
(5)\end{array}$ & $\begin{array}{c}1203 \\
(91)\end{array}$ & $\begin{array}{l}67 \\
(5)\end{array}$ & $\begin{array}{l}45 \\
(3)\end{array}$ \\
\hline Up to 3000 & $\begin{array}{c}953 \\
(100)\end{array}$ & $\begin{array}{l}374 \\
(39)\end{array}$ & $\begin{array}{l}259 \\
(27)\end{array}$ & $\begin{array}{l}276 \\
(29)\end{array}$ & $\begin{array}{c}6 \\
(1)\end{array}$ & $\begin{array}{l}38 \\
(4)\end{array}$ & $\begin{array}{l}868 \\
(91)\end{array}$ & $\begin{array}{l}52 \\
(5)\end{array}$ & $\begin{array}{l}33 \\
(4)\end{array}$ \\
\hline $3001-6000$ & $\begin{array}{l}1874 \\
(100)\end{array}$ & $\begin{array}{l}862 \\
(46)\end{array}$ & $\begin{array}{l}394 \\
(21)\end{array}$ & $\begin{array}{l}516 \\
(28)\end{array}$ & $\begin{array}{c}6 \\
(n)\end{array}$ & $\begin{array}{l}96 \\
(5)\end{array}$ & $\begin{array}{r}1724 \\
(92)\end{array}$ & $\begin{array}{l}87 \\
(5)\end{array}$ & $\begin{array}{l}63 \\
(3)\end{array}$ \\
\hline $6001-9000$ & $\begin{array}{l}2323 \\
(100)\end{array}$ & $\begin{array}{l}905 \\
(39)\end{array}$ & $\begin{array}{l}516 \\
(22)\end{array}$ & $\begin{array}{l}810 \\
(35)\end{array}$ & $\begin{array}{c}3 \\
(\mathrm{n})\end{array}$ & $\begin{array}{l}89 \\
(4)\end{array}$ & $\begin{array}{c}2130 \\
(92)\end{array}$ & $\begin{array}{r}124 \\
(5)\end{array}$ & $\begin{array}{l}69 \\
(3)\end{array}$ \\
\hline Over 9000 & $\begin{array}{l}3136 \\
(100)\end{array}$ & $\begin{array}{r}1454 \\
(46)\end{array}$ & $\begin{array}{l}516 \\
(16)\end{array}$ & $\begin{array}{l}889 \\
(28)\end{array}$ & $\begin{array}{l}53 \\
(2)\end{array}$ & $\begin{array}{r}224 \\
(7)\end{array}$ & $\begin{array}{r}2890 \\
(92)\end{array}$ & $\begin{array}{r}137 \\
(4)\end{array}$ & $\begin{array}{r}109 \\
(3)\end{array}$ \\
\hline $\begin{array}{l}\text { Southern India } \\
(1979-80)\end{array}$ & $\begin{array}{l}1562 \\
(100)\end{array}$ & $\begin{array}{l}489 \\
(31)\end{array}$ & $\begin{array}{l}434 \\
(28)\end{array}$ & $\begin{array}{l}554 \\
(35)\end{array}$ & $\begin{array}{c}9 \\
(1)\end{array}$ & $\begin{array}{l}76 \\
(5)\end{array}$ & $\begin{array}{l}915 \\
(59)\end{array}$ & $\begin{array}{l}588 \\
(38)\end{array}$ & $\begin{array}{l}59 \\
(4)\end{array}$ \\
\hline Up to 3000 & $\begin{array}{l}1432 \\
(100)\end{array}$ & $\begin{array}{l}455 \\
(32)\end{array}$ & $\begin{array}{l}368 \\
(26)\end{array}$ & $\begin{array}{l}557 \\
(39)\end{array}$ & $\begin{array}{c}1 \\
(\mathrm{n})\end{array}$ & $\begin{array}{l}51 \\
(4)\end{array}$ & $\begin{array}{l}863 \\
(60)\end{array}$ & $\begin{array}{l}519 \\
(36)\end{array}$ & $\begin{array}{l}50 \\
(4)\end{array}$ \\
\hline $3001-8000$ & $\begin{array}{l}1781 \\
(100)\end{array}$ & $\begin{array}{l}549 \\
(31)\end{array}$ & $\begin{array}{l}554 \\
(31)\end{array}$ & $\begin{array}{l}542 \\
(30)\end{array}$ & $\begin{array}{l}22 \\
(1)\end{array}$ & $\begin{array}{r}114 \\
(6)\end{array}$ & $\begin{array}{l}997 \\
(56)\end{array}$ & $\begin{array}{l}711 \\
(40)\end{array}$ & $\begin{array}{l}73 \\
(4)\end{array}$ \\
\hline Over 8000 & $\begin{array}{l}2347 \\
(100)\end{array}$ & $\begin{array}{l}687 \\
(29)\end{array}$ & $\begin{array}{l}593 \\
(25)\end{array}$ & $\begin{array}{l}694 \\
(30)\end{array}$ & $\begin{array}{l}44 \\
(2)\end{array}$ & $\begin{array}{l}329 \\
(14)\end{array}$ & $\begin{array}{r}1337 \\
(57)\end{array}$ & $\begin{array}{l}843 \\
(36)\end{array}$ & $\begin{array}{r}167 \\
(7)\end{array}$ \\
\hline
\end{tabular}

Notes: Figures are kilograms of coal replacement.

Figures in brackets give the percentage of total energy used; $n=$ negligible.

* Figures also include space heating in the case of Northern India.

Source: NCAER 1981:105, 107; ITES 1981:424, 425. 
firewood per household with farm size [Howes and Jabbar, 1986].

In much of rural South Asia, firewood and other domestic fuels such as crop residues and dung are gathered, and seldom purchased. In parts of Nepal and Bangladesh all firewood needs are met by selfcollection. In rural North India only an estimated 26 per cent of firewood, 9 per cent of dung and 5 per cent of crop wastes are purchased; for rural South India the percentages are 10,5 and 5 respectively [NCAER 1981; ITES 1981]. The bulk of the domestic fuel is gathered by households from their own resources or from common land and forests, or from the land of others.

As asset holdings decline, the dependency on fuel collection from sources other than one's own increases. Landed rural households can obtain firewood (often through hired labour) from trees located on their own land, residues from their crops, and dung from the cattle they own. The landless, however, have to depend for firewood and supplementary fuel on forest and common land or obtain it from other people's land in return for work done. This dependence is clearly brought out in Table 3 , covering the semi-arid areas of five Indian States. It is noteworthy that common property resources (CPRs) which are of marginal importance as fuel sources for the larger farmers, provide $66-84$ per cent (varying by region) of the domestic fuel and 91-100 per cent of the firewood consumed by small farmer and landless households.

The overall dependency of the rural population on self-collection of domestic fuel, and the dependency of the rural poor in particular on common land, leads to significant variations in fuel (and especially firewood) consumption by ecological regions (particularly due to differences in locational availability) and by income class of household within the region. Table 4 clearly brings out these differences. In North India, for instance, the firewood consumed per rural household in the hills is twice as much as in the plains in absolute terms, and almost twice as much in terms of the percentage of total domestic fuel used. Equally striking is the positive relationship between income group and the amount of firewood consumed consumption decreases consistently as income levels

\section{Table 3 Domestic fuel consumption by household economic position and source of fuel in rural India}

\begin{tabular}{|c|c|c|c|c|c|c|c|}
\hline \multirow[t]{3}{*}{ District/State } & \multirow{3}{*}{\multicolumn{2}{|c|}{$\begin{array}{c}\text { Household's } \\
\text { economic } \\
\text { position }\end{array}$}} & \multirow{3}{*}{$\begin{array}{c}\text { Weekly fuel } \\
\text { consumption } \\
\text { per household } \\
(\mathrm{kg})\end{array}$} & \multicolumn{4}{|c|}{ Per cent fuel from } \\
\hline & & & & \multirow[t]{2}{*}{ CPRs } & \multicolumn{3}{|c|}{ Own Sources } \\
\hline & & & & & Firewood & Dung & $\begin{array}{l}\text { Crop } \\
\text { residues }\end{array}$ \\
\hline Mahbubnagar & Poor & (13) & 119 & 84 & - & 9 & 8 \\
\hline (Andhra Pradesh) & Others & (7) & 190 & 13 & 26 & 41 & 20 \\
\hline Akola & Poor & (13) & 104 & 79 & - & 3 & 18 \\
\hline (Maharashtra) & Others & (7) & 185 & 13 & 20 & 24 & 43 \\
\hline Sholapur & Poor & (13) & 119 & 72 & 2 & 12 & 14 \\
\hline (Maharashtra) & Others & (7) & 205 & 10 & 18 & 34 & 38 \\
\hline Sabarkantha & Poor & & 184 & 66 & - & 25 & 9 \\
\hline (Gujarat) & Others & (10) & 213 & 8 & 18 & 28 & 46 \\
\hline Raisen & Poor & (20) & 185 & 74 & 9 & 11 & 6 \\
\hline (Madhya Pradesh) & Others & (10) & 219 & 32 & 24 & 29 & 15 \\
\hline
\end{tabular}

Notes: 'Poor' includes agricultural labourer and small farmer (with $<2$ ha of dry land equivalent) households; 'Others' includes only large farmer households (i.e. the top $20 \%$ of landowners in the village).

Figures in brackets give sample size.

CPRs: Common Property Resources.

Source: Jodha 1986:1173 


\begin{tabular}{|c|c|c|c|c|c|c|c|c|}
\hline \multirow{2}{*}{$\begin{array}{l}\text { Income class/Region } \\
\text { (Rs./year) }\end{array}$} & \multicolumn{2}{|c|}{ Hills } & \multicolumn{2}{|c|}{ Plains } & \multicolumn{2}{|c|}{ Desert } & \multicolumn{2}{|c|}{ All Regions } \\
\hline & $k g C R$ & $\% T D E C^{*}$ & $k g C R$ & $\%$ TDEC & $k g C R$ & $\% T D E C$ & $k g C R$ & $\% T D E C$ \\
\hline $\begin{array}{l}\text { Northern India } \\
1975-76\end{array}$ & $\begin{array}{c}1103 \\
(1656)\end{array}$ & 67 & $\begin{array}{c}466 \\
(1275)\end{array}$ & 36 & $\begin{array}{c}822 \\
(1271)\end{array}$ & 65 & $\begin{array}{c}551 \\
(1315)\end{array}$ & 42 \\
\hline Up to 3000 & 926 & 67 & 293 & 32 & 624 & 67 & 374 & 39 \\
\hline 3001 to 6000 & 1310 & 65 & 774 & 42 & 1072 & 61 & 862 & 46 \\
\hline 6001 to 9000 & 1663 & 59 & 795 & 35 & 1571 & 69 & 905 & 39 \\
\hline \multirow[t]{2}{*}{ Over 9000} & 2320 & 82 & 1362 & 43 & 1661 & 65 & 1454 & 46 \\
\hline & \multicolumn{2}{|c|}{ Hills } & \multicolumn{2}{|c|}{ Plains } & \multicolumn{2}{|c|}{ Coastal } & \multicolumn{2}{|c|}{ All Regions } \\
\hline $\begin{array}{l}\text { Southern India } \\
1979-80\end{array}$ & $\begin{array}{r}549 \\
(1612)\end{array}$ & 34 & $\begin{array}{c}584 \\
(1728)\end{array}$ & 34 & $\begin{array}{c}362 \\
(1367)\end{array}$ & 26 & $\begin{array}{c}489 \\
(1562)\end{array}$ & 31 \\
\hline Up to 3000 & 534 & 36 & 568 & 34 & 294 & 25 & 455 & 32 \\
\hline 3001 to 8000 & 571 & 32 & 604 & 33 & 484 & 28 & 549 & 31 \\
\hline Over 8000 & 806 & 23 & 1084 & 44 & 412 & 22 & 686 & 29 \\
\hline
\end{tabular}

Notes: $\mathrm{CR}=$ Coal replacement; $\mathrm{TDEC}=$ Total Domestic Energy Consumption.

* per cent of firewood energy in TDEC in respective income class and region.

Figures in brackets give the TDEC for the region as a whole.

Sources: NCAER 1981:105, 107; ITES 1981:424, 426-8.

fall in each region. Table 3 provides additional evidence of a clear positive association between all domestic fuel consumed and the household's access to land. In other words, a household's land holding status affects not only its access to food but also to the fuel to cook it. And the greater the concentration of land and cattle ownership, the greater are likely to be the inequalities in access to fuel. Village studies by Briscoe (1979) and Islam (1980) in Bangladesh clearly highlight this. Briscoe found that 89 per cent of all fruit and firewood trees in the village were owned by 16 per cent of the families, who also owned 55 per cent of the cropped land and 46 per cent of the cattle. Islam similarly found that 52.3 per cent of the trees in the six villages he surveyed were owned by 11.4 per cent of the households.

With increasing deforestation and the degradation as well as declining availability of common land, these differences are likely to be strengthened further. Jodha's (1983, 1986) research for India indicates that over the past three decades the area and productivity of CPRs has declined by $26-63$ per cent (varying by region) due to the privatisation of this land in favour of the larger landed households, forcing the landless and near landless to depend on decreasing tracts of common land. In addition (as elaborated later) the green revolution technology has reduced the avail- ability of crop and animal wastes to the poor in complex ways. Growing urban demands have also accelerated the commercialisation of firewood, the prices of which have more than doubled over the last decade in much of South Asia, and increased tenfold over the past two decades in several cities.

Basically, as firewood, crop residues and dung get scarcer and increasingly monetised, those who have no fuel-yielding assets and little purchasing power will tend to get squeezed out. For such households, there can even be a trade-off between fuel and food. For instance, in rural Bangladesh, landless Hindus who are typically economically and socially the worst off, have to buy firewood during the monsoon when crop residues are not available, at the cost of buying food [Briscoe 1979].

Particularly revealing in this regard is Howes and Jabbar's (1986) study of a sample of Bangladeshi households, which gives information on changes over the past ten years of the average number of all meals and cooked meals consumed daily by different classes of households (big farmers, owner-cultivators, sharecroppers and landless). While the big farmers can still afford three meals (almost all cooked) a day, the small owner cultivators and sharecroppers have shown a small decrease, and the landless a significant decrease, 
both in the total number of meals consumed and the number of cooked meals consumed.

Women in poor households bear the highest burden. As the main gatherers of fuel it is primarily their time and effort that is extended with shortages. Also, they (and female children) face more severe nutritional consequences from such shortages than males because of a systematic bias against them in the distribution of food within the family [Agarwal 1986b]. This unequal distribution and poverty mean, too, that the women are unlikely to get the extra food necessary to make up for the additional energy they expend in fuel collection. Further, as other sources of livelihood get eroded, selling firewood for an income is becoming increasingly common among the poor in many parts of South Asia (especially in eastern India, Nepal and Bangladesh). By one estimate, two to three million rural people in India are so dependent. Most of them are women, earning a meagre Rs.5.50 or so a day for a headload of $20 \mathrm{~kg}$ of wood [Agarwal and Deshingkar 1983].

At the macro-level, by FAO estimates, some $1.4 \mathrm{bn}$ people in rural Asia and the Pacific are likely to be facing an acute scarcity of woodfuel in the year 2000 . This includes, in particular, people in India, Pakistan, Nepal and Bangladesh. And within these countries, it will include essentially the poor, especially in the semiarid regions.

\section{What Factors underlie the Crisis?}

Impinging on this crisis is a complex set of interrelated issues: i) the absolute availability of wood for all uses (which depends on the tree resources of the country, barring imports); ii) the availability of wood for fuel (which depends on the distribution of existing wood supplies between different uses); iii) the availability of woodfuel to the poor (which depends on the distribution of wood supplies between people). As elaborated below, firewood shortages being faced by the poor today emerge from the particular uses to which forest land and wood resources have been put over the years by specific classes of people, and cannot be traced in any straightforward way to the gathering of firewood by the poor for their domestic use. Historically, under British rule, there was virtually indiscriminate forest exploitation in India through European and Indian private contractors, especially for the expansion of railways in the mid-19th century and for building ships, bridges, etc. in the inter-World War years. As documented by British observers [see Guha 1983], large tracts of forests in the Garhwal and Kumaon hills were 'felled in even to desolation', often without adequate supervision, so that 'thousands of trees were felled which were never removed nor was their removal possible'. Vast areas of mountain forest were also given away to selected individuals to set up tea and coffee plantations, in addition to encouraging forest clearance for crop cultivation to augment the colonial government's land revenues. Nepal, while not directly under colonial rule, was strongly influenced and guided by the British Indian Forest Services and experienced considerable intensive felling, especially during the 1920s and 1930s [Bajracharya 1983].

The cutting of forests for commercial use has continued in the post-colonial period to provide building logs, industrial raw material especially to the paper manufacturers, fuel to small-scale and cottage industries, etc. Forest land has also been lost due to mining, stone quarrying, agriculture and large river valley projects. According to official statistics for India, between 1951-52 and 1975-76, 4.14 $\mathrm{mn}$ ha were deforested - agriculture and river valley projects accounting for 60.2 per cent and 11.6 per cent of this area respectively. However, Forest Department statistics, even on total forested area, were subsequently shown to be very wide of the mark by National Remote Sensing Agency data. These revealed that in $1972-75,55.5 \mathrm{mn}$ ha or 16.9 per cent of land was forested (the official claim being 23 per cent) which by 1980-81 had fallen to $46.4 \mathrm{mn}$ ha or 14.1 per cent - an annual fall of $1.3 \mathrm{mn}$ ha. In fact a good deal of felling continues to be illegal, and no clearcut estimates yet exist on what proportion of the forests are being cut for which purposes and at what rates.

What is noteworthy, however, is that the use of wood for almost all purposes other than as a domestic fuel in the rural areas requires the cutting down of trees. Firewood in contrast can be collected in the form of twigs and fallen branches which does not lead to tree destruction. And both micro- and macro-studies indicate that this in fact is the form in which firewood is typically gathered. Briscoe finds this in his Bangladesh village study; in Pura village [Karnataka, India] 91 per cent of the firewood is consumed in this form [Ravindranath, et al, 1978]; and NCAER (1981) estimates that nearly 75 per cent of the firewood used as domestic fuel in rural North India is in the form of twigs and branches. Interestingly, to the extent that logs are burnt as domestic fuel, the culprits are noted to be the higher income groups and not the poor.

In short, the link between deforestation (and associated firewood shortages) and domestic firewood consumption by the poor is a tenuous one. And even to the extent that in some areas trees are being cut or the barks of trees being stripped off by the poor to obtain fuel, it must be seen as a symptom of the crisis - a reaction of the people who are the severest hit but who cannot be held responsible for having caused the crisis.

This becomes even more apparent when we examine what has been happening to the access of the poor to CPRs on the one hand and to forests on the other. Both Jodha's (1983, 1986) work on India (mentioned earlier) and Cernea's (1981) study on the Azad 
Kashmir area of Pakistan point to the gradual appropriation of CPRs by large farmers. Jodha attributes this largely to the way land reform programmes in the 1950 s and subsequent welfare schemes were implemented, whereby considerable areas of CPRs were demarcated for distribution to the landless, but in practice much of the land so privatised went to the larger farmers. In Rajasthan, for instance, in the villages he surveyed, the landless received only 14-24 per cent (varying by district) of the land distributed - almost all of it of poor quality. And by the time of the survey they had lost control over much of even this - having sold or mortgaged it due to its poor quality and/or the lack of resources to develop it. Hence the collective loss of CPRs by the poor was not made up by their privatised gain. A similar trend of de facto appropriation of community land by large farmers in Azad Kashmir is described by Cernea.

Likewise, the history of forest policy in the subcontinent reveals the systematic marginalisation and uprooting of tribal populations by various State schemes - such as the settlement of non-tribals on tribal land, and the reservation of forests (in effect barring them from entering areas on which they depended for a livelihood).

As Guha (1983) notes, the Forest Department was created in India in 1864 under colonial rule and was accompanied by legislation curtailing the previously unlimited rights of users over forest produce, giving the State monopoly rights over land. Various Forest Acts sought to establish that the customary use of forests by the villagers was based not on 'rights' but on 'privilege' which could only be exercised at the discretion of the local rulers. Large tracts of forest were also fenced off, increasing the population pressure on the remaining land. Practices of shifting agriculture had earlier incorporated long fallows allowing adequate time for regeneration. Also, the adaptation of tribal communities to population growth took the form of the gradual development of orchards and settled farming alongside swidden. Today increasing numbers are being forced to survive on diminishing tracts of 'common' forest which they are then held responsible for destroying. Here the issue is not one of 'weaning the tribal population from shifting agriculture' by 'careful demonstration of improved methods' and 'persuasive means' [see Novak and Polycarpau 1969] but of the absence of alternative sources of livelihood, and the erosion of community life in which the social and the economic had earlier been closely interwoven in ways conducive to preserving the environmental balance.

There is also evidence from all over South Asia of the exploitation of tribals by the forest guards (who are usually placed at the lowest rung of the Forest Service hierarchy). There are examples from different parts of India of guards taking a share of the value of minor forest produce collected by the tribals, of making them work without wages, of collecting regular tributes from them and implicating non-givers in legal cases with the connivance of the local police, of meting out punishments at the smallest transgression into the socalled reserve forests, of levying huge fines (for which no receipt is given) for minor offences, and even of beating tribals mercilessly on the smallest pretext [see Joshi 1981; Chand and Bezboruah 1980; Swaminathan 1982a]. Similarly, in the Azad Kashmir region in Pakistan, 50,000 cases of forest offences are noted to be pending in courts, with one family in every six being implicated in a reported offence [Cernea 1981]. In Bangladesh again, a ten village study revealed numerous cases of harassment of the landless by local police and forest officials [BRAC 1980:73-6].

Not surprisingly perhaps, today there is noted to be a widespread feeling that the forest officials are 'instruments of the government (which is distant and threatening)' and exploiters who take bribes, harass, threaten and extort in the name of unfamiliar laws, and who are gradually taking away from the people their natural habitat - namely the forest [Roy 1980].

Ninan (1983) attributes the behaviour of guards in the Indian Forest Service to low salaries ('a guard who polices several lakh rupees worth of valuable forest is paid only Rs. 300 per month'), and to hierarchies in the Service. She emphasises the need to reduce inequalities in the Service and to crack down on the culture of blatant corruption. How this can be done in a structure built on hierarchies and privilege is a moot question.

Also corruption is not limited to the guards. A Bangladesh case sti:dy documents the illegal cutting of trees on government land by locally powerful timber merchants, with the unofficial cooperation (via bribes) of Forest Officers. The merchants bought plots, situated inside the government forests, from the tribals at very cheap rates; and obtained permits to fell trees on these plots. But this land had few trees, and 90 per cent of the trees they actually cut were on the government land adjacent to their plots [BRAC 1980]. Nath (1968) documents a similar case of the illegal exploitation of government forests and local tribal land by timber merchants in Madhya Pradesh, India. In this context, it is especially pertinent to ask: 'For whom are these forests reserved? Protected for whom? Protected from whom? [Swaminathan 1982a:344].

Firewood shortages apart, the domestic fuel crisis has been further exacerbated by the adverse effect of the green revolution technology on the availability of crop residues and dung to the poor. For instance, shifts in cropping patterns in parts of Bangladesh, with jute being replaced extensively by tubewell irrigated HYV boro rice, has reduced the availability of jute sticks for fuel which formed a significant part of the payment to female hired labour [Howes and Jabbar, 1986]. Also, 
high yielding dwarf crop varieties relative to traditional varieties give lesser crop residue per unit weight of grain which is not necessarily made up by higher per acre crop output. Further, in recent years, combine harvesters are becoming increasingly popular among the Indian farmers (as in Punjab and Haryana). These displace labour and leave virtually no crop residues. In contrast, under manual harvesting, employment is higher and labourers are often paid in grain along with the straw or stalks. Again, tubewell irrigation in semi-arid areas (as in Kolar district, Karnataka) has led to a significant drop in the water table, further degrading CPRs. Also, in general, with the spread of irrigation it is now more profitable to use dung as manure, leaving less for the labourers to forage as fuel. In fact, by one estimate, between 1963-64 and 1973-74 there has been a decline in the dung burnt as fuel in India, even while dung output in general and that used as manure has increased [Desai 1980].

Changing production relations in agriculture, and the growing scarcity of biomass is also leading to modifications in tenancy contracts: in parts of Bangladesh sharecroppers now have to give the landlord not just half the crop but half the crop residues too [Howes and Jabbar, 1986]. Also, with the new agricultural technology, there is a trend in many parts of South Asia towards resumption of land under personal cultivation, with a consequent decline in leased out land and increasing landlessness. This is forcing increasing numbers to depend on uncertain fuel supplies from diminishing tracts of common resources.

Ultimately, therefore, the distribution of energy resources between uses and users impinge on central aspects of political economy - on the distribution of material wealth and political power between different classes and social groups within the country, which determines who gets across to how much of a scarce resource, and for what purpose.

These aspects of political economy which underlie the domestic fuel crisis facing the poor also overshadow attempts to alleviate it. This emerges clearly from the experience of tree-planting schemes, a very large number of which have been initiated in the past few years by national and international agencies, usually under the banner of a catch-all phrase - 'social forestry' - and which are now being promoted as the solution to both the firewood crisis and the environmental crisis.

\section{The Experience of Tree-Planting Schemes}

Tree production can be promoted under individual, government or community management, on private, government or community (belonging jointly to a village or group) land, for commercial or non- commercial use. 'Farm forestry' usually implies individuals growing trees (to sell or for own use) on private land. 'Social forestry' on the other hand implies the planting of trees for meeting the needs (especially of fuel and fodder) of the rural people, usually through the use of government or community land, under government or community management. Such planting when undertaken by the community (typically on village land) is also often termed 'community forestry'.

In recent years, numerous schemes under all three systems of management and on different types of land, have been launched, many funded by international aid agencies such as FAO, SIDA, World Bank and USAID. Yet available evaluation studies (some detailed, some impressionistic) indicate that while farm forestry has had a limited success in parts of South Asia, social forestry, with very few exceptions, has been a failure in most places, even in the sense of ensuring the planting and maturing of trees, let alone in providing for the daily needs for fuel, fodder, etc. of the rural poor.

\section{(i) Tree Planting by the Government}

Many of the schemes where the governments have directly taken charge of tree planting have been introduced in opposition to the wishes of the people rather than with their support. This is especially so where the reservation of degraded forest land for tree planting has restricted or terminated the rights of farmers, cattle grazers or hunters to the hitherto 'free' produce of the forest. Such reservations have particularly hit tribal communities whose main sustenance has come from the forests for generations. Also the restrictions have usually been imposed from above without the involvement of the local community in the decision.

In some cases, land has been taken over to plant trees solely for commercial purposes. There are several examples of this from India. In Bihar, the Forest Department sought to replace a mixed forest by a monoculture teak plantation. Not only were the teak trees of no immediate use to the people, but the establishment of the plantation deprived the tribals of existing rights to collect minor forest produce. As a result, the local residents axed many of the teak trees, to deter the extension of the plantations at the cost of their mixed forest [Makhijani 1979]. Again, in Midnapore district (West Bengal), eucalyptus and other commercial varieties are noted to have been forcibly planted by the Forest Department on plots where the tribals originally grew paddy (Indian Express 1983]. In Uttar Pradesh, sheesham and sal were cut to plant eucalyptus [Dogra 1984]. Likewise in Bastar district (Madhya Pradesh) under a World Bank-funded project, 40,000 ha of deciduous forest were to be clear-felled to plant tropical pine as raw 
material for the paper industry. This brought strong resistance from the tribals, led to a public controversy and the eventual shelving of the scheme [Guha 1983; D'Monte 1982].

Problems with government programmes stem not only from the land use policy of the Forest Department but also from the attitudes and practices of the Forest Officials who in India (as also elsewhere in Asia) are noted to be typically 'tree oriented' and not 'people oriented'. Hence, even while the officials may accept that community forestry is for the people, they are still far from saying that it is by the people. They seek to decide what is good for the community rather than letting the community decide what is good for them and help them in doing it [Roy 1980].

In several cases people's own initiatives are found to have been thwarted by forest authorities through lengthy bureaucratic procedures and unhelpful attitudes [UTTAN 1983; Swaminathan 1982b]. In many others, trees planted by villagers on their private land have been claimed by the government as its property [Sarin 1980; Romm 1979]. Here the villagers now refuse to plant trees without a written assurance that those planted on their land are their property.

All said, both the protection of existing forests and the government's new tree planting schemes, far from benefiting the rural poor have, in most cases, further deprived them of their existing rights. Essentially, these projects, undertaken in the name of social forestry, provide no guarantee that the benefits will flow to the people, and especially to those who put in the labour. The absence of such a surety also underlies the failure of most of the so-called community forestry schemes, to which I shall now turn.

\section{(ii) Community Forestry Schemes}

The assumption in such schemes is that the community will actively participate in tree planting. Yet, on the one hand, little effort is made by the scheme initiators to actively involve the people in scheme conceptualisation and implementation; and, on the other, the unequal pattern of land ownership and control, and the power structures operating in the village, circumvent voluntary participation by the underprivileged. Consider a project in the Azad Kashmir region of Pakistan, where it was assumed that tree plantations would come up on three types of land: Shamlat (community), government and private. Planting on Shamlat land was meant to ensure that the main benefits would flow to the small farmers who were in a majority in the community but had little access to firewood; this was also expected to promote direct community participation. Planting on the government land was to demonstrate the benefits of the fast-growing tree species to the farmers, to induce them to plant trees on their own land.

In practice, the project's success lay mainly in its promotion of private tree planting by the larger farmers. The latter were also willing to invest in the Shamlat land but the smaller farmers were unwilling to do so. Cernea describes the underlying reasons for the failure of community forestry. While in legal terms Shamlat land continues to be considered community land, in reality much of it is operated as private land. Also, the usufruct benefits from the so-called Shamlat land accrue to the larger farmers rather than to the community as a group. The de facto owners hope to get the lands planted at full government expense with no repayment commitment, and also in the process restrict the current rights to fodder and grass which the small farmers enjoy over this land. The latter are thus unwilling to put in labour for planting trees on this land, as not only is the prospect of their getting any benefits low but their limited rights to grazing, etc. are also in danger of being lost.

This is in fact a familiar story in the subcontinent. And this de facto control by village factions over community land crucially affects village forestry schemes. In both Gujarat and Uttar Pradesh (India), in World Bank-aided forestry projects started in the early 1980 s, the village self-help woodlot components have largely failed. A mid-term appraisal report for Gujarat attributed the lack of success to the nonhomogeneous nature of the village community, the mistrust in the system regarding its ability to ensure equitable distribution of woodlot output, disputes among farmers on the availability of common land for establishing village woodlots, and so on [World Bank 1983a].

The clear pointer from these experiences is the particular difficulty, if not impossibility, of successfully implementing such schemes within agrarian structures that are characterised by sharp socioeconomic inequalities. The lesson is reinforced when we examine the few success stories.

In the Indian context, one of the noteworthy cases of successful community mobilisation for tree protection and planting - the Chipko Movement - comes from the hills of Uttar Pradesh, where 95 per cent of the forest land is owned by the government and managed by the Forest Department. The Movement was mainly sparked off in 1972-73 by the people in Chamoli district protesting against the allotment of vast tracts of ash forest for felling to a sports goods manufacturer, while a local labour cooperative was refused permission to cut a few trees for making agricultural implements for the community. The villagers (including women), mobilised by the cooperative, resorted to Chipko (meaning to cling to or embrace the trees), challenging the employees of the sports goods company to axe them first. Since then people in the region have sought to end the contractor system of forest exploitation, demanded a ban on green felling and excessive resin tapping, and agitated 
for minimum wages for forest labourers. In several instances peaceful protest demonstrations by Chipko activists have led to the cancellation of tree auctions [Dogra 1984]. The campaign is now focused both on tree protection and reforestation. Women in particular, have been at the forefront both in the protest demonstrations and in keeping vigilance against illegal felling.

The Movement has also highlighted the fact that women and men, even of the same class of household, can have different priorities, and that the interests and concerns of the women tend to be much more directly related to ecological preservation. For example, in 1980 , a government scheme to cut down a large tract of the Dungari-Paitoli oak forest (in Chamoli district), to establish a potato seed farm and other infrastructure, was strongly and successfully opposed by the local women who resorted to Chipko to save the trees. The scheme was supported by the village men (especially those of the village council) who saw in it the potential for profit. The women, however, argued that forest destruction would take away their main source of fuel, fodder and water, while cash in the man's hands was likely to be frittered away on tobacco and alcohol. It was women in this region who raised the slogan: 'Planning without fodder, fuel and water is one-eyed planning'. A campaign to fight male alcoholism has also been launched. And in some villages women are demanding an equal say with men in village decisionmaking, especially on forestry issues, and asking: Why aren't we members of the village councils? [Jain 1984]. The Chipko Movement thus has the potential for growing from an ecology movement to one which calls for an end to exploitation at several levels.

At the same time, one cannot ignore the specificities of the Chipko area. The Movement essentially involves hill communities which are not characterised by sharp class and caste inequalities, and where women in particular have always played a significant role in the agrarian economy without being subject to the rigid norms of seclusion typically prevalent in the plains of North-West India. It is questionable whether elsewhere in India, in a different socioeconomic context, such community mobilisation would be as readily possible.

In this context, it is also noteworthy that the two best-known examples of social forestry in Asia that may be termed successful on a country-wide basis, and not just in localised schemes or areas, are South Korea and China. The two countries differ widely in their political systems, but in both of them the schemes were introduced within relatively egalitarian structures, brought about by radical agrarian reforms undertaken in the 1950s. Of course their ability to implement the reforms or to mobilise the people for community schemes cannot be separated from their political systems or from their cultural backgrounds.
In much of South Asia, however, there is a highly unequal distribution in the ownership and control of land, which usually constitutes the main source of wealth and represents the principal source of economic and political power, especially in the rural areas of these societies. In the absence of redistributive land reform, community involvement in such schemes is likely to be extremely difficult in most cases, and in some perhaps not feasible. This is borne out not only by the forestry related programmes but also by the vast literature on rural development schemes in general which points to the failure of cooperative ventures to benefit the poor, in the Indian subcontinent and elsewhere, unless the cooperatives are composed of people relatively equal in economic and social terms.

With existing village level inequalities there is in fact a danger of promoting farm forestry which typically does not offer a real solution to the woodfuel crisis and can have several undesirable consequences (as discussed below).

\section{(iii) Farm Forestry}

In recent years, the much-quoted success stories of tree-planting projects in India relate to planting on private land for commercial use, such as in Gujarat and Uttar Pradesh (UP). In Gujarat, under the World Bank-aided project mentioned earlier, between 198081 and $1982-83,32,000$ ha were planted under farm forestry, which is about twice the area targeted, while the achievements in village self-help woodlots fell short of targets by 57 per cent. The bulk of these private plantings have been undertaken by the betteroff farmers on land previously under crops and often irrigated. The species planted (eucalyptus is a favourite) are fast-growing and commercially in great demand, as the prices of poles and pulpwood have escalated in recent years. The actual gains have accrued to only six per cent of Gujarat's $2.4 \mathrm{mn}$ farm families. While tree planting on governmentsupervised woodlots has also been reasonably successful there is no certainty that such wood will be made available to the people, and at a sufficiently low price.

The case of UP is similar. Here, between 1979-80 and 1982-83, the area planted under farm forestry was 3433 per cent of that targeted, while village self-help woodlots fell short of targets by 92 per cent. The most responsive farmers were those with holdings of 2 ha or more and the trees planted were again commercial species for providing building poles [World Bank 1983b]. Both these have been termed 'social forestry' projects but in effect have done little to satisfy the aims of social forestry, namely the provision of fuelwood, etc. for the domestic needs of the rural people.

In fact the schemes can have several dangerous longterm consequences. First, the shift of large areas of 
fertile land (irrigated and rainfed) from food to commercial wood production will reduce the availability of food and fibre in the country. These shifts have been observed in States other than Uttar Pradesh and Gujarat. In the semi-arid Kolar district of Karnataka, for example, Bandyopadhyay (1981) notes that several thousand hectares of agricultural land have been shifted from crops to sericulture and commercial forest plantations. Today, in Kolar district, 16,216 ha (86 per cent irrigated) is under mulberry, about 20,000 ha under eucalyptus and 6,710 ha under casuarina. The most significant shift has been from ragi, the staple millet crop of the people, to eucalyptus: farm area under ragi in this district is observed to have declined dra matically in recent years. Eucalyptus is also the species that is to be planted on 45.5 per cent of the 110,000 ha of farm land that will be afforested under a World Bank-aided social forestry project in the State.

Second, the shift from food crops to tree production (which is less labour intensive) will reduce employment. In the proposed World Bank-aided Karnataka project eucalyptus monoculture will lead to an estimated loss of $137.5 \mathrm{mn}$ person days of employment [Bandhyopadhyay 1981]. Third, the noted shifts are likely to be ecologically destructive where commercial species, which deplete the soil of nutrients and water, replace the present system of mixed or rotation crop farming [e.g. the ragi-pulses-oilseeds rotation] that maintains soil stability. Fourth, farm forestry will have a particularly adverse effect on the poor due to lower employment opportunities, faster-rising food prices, and less access to crop waste for fuel. (Eucalyptus leaves cannot be used for fodder and the wood is unsuitable as a cooking fuel since its burning velocity is too high.) In other words, farm forestry is not only unlikely to solve the problem of woodfuel shortages but will probably accentuate the crisis for the poor.

Yet such schemes are being promoted with shortsighted zeal. In fact the Gujarat project is publicised as the success story of social forestry in India. And the earlier quoted mid-term appraisal report for this project, despite noting that farm forestry has been essentially commercial forestry in Gujarat, and that village self-help woodlots (which were the main hope for supplying firewood) have failed, heroically concludes: 'It seems possible, that if the present momentum is maintained, it will be possible to resolve the rural fuelwood crisis in Gujarat within a decade' [World Bank 1983a].

In many cases such schemes are being defended on grounds of profit maximisation. Some note that farmers in Gujarat can annually earn Rs. 15,000 per acre or more with eucalyptus relative to Rs. 1000 or less with groundnuts, and conclude that this profit motive must be encouraged still further [Bapat 1983]. Others argue that after a point there will be a glut in eucalyptus, leading farmers to diversify their plantations and grow other species [Jha 1983; World Bank 1983a]. However, thus far, demand considerably exceeds supply; and in any case since it is the profit motive that is sustaining eucalyptus production, it is unlikely that slow-growing trees, which will not yield similar short-term gains, will be planted subsequently. Also, yields (whether of other tree-crops or agricultural crops) on the land left depleted by monoculture eucalyptus plantations are likely to be low, unless adequate investment is undertaken to restore soil fertility.

The fact is that the current farm forestry policy in India is not the answer to the problem of firewood shortages faced by the poor. At the same time, the issue of social forestry is intricately linked to the social structure and mechanisms of socioeconomic control which determine who benefits and to what extent from the use of scarce resources. It cannot, as one observer rightly notes 'be reduced to a simple ritual of planting trees' [Agarwal 1983].

\section{Concluding Comments}

It is amply clear that the success of social forestry schemes, viz. the planting of trees to increase available supplies of firewood for the local population, is crucial to alleviating the domestic fuel crisis. At the same time, as with many other rural development programmes, the issue of increased firewood production needs to be linked structurally to that of distribution if the schemes are to fulfil their intended aim. De-linking the two aspects, as has happened in the thrust towards farm forestry in India, has meant not only that the benefits of increasing production go to only a few, but that the product itself is inappropriate for fulfilling domestic fuel needs. Social/community forestry provides the potential for making this link between production and distribution. But the success of such schemes, as noted, requires close community involvement and participation, ideally at all levels and at every stage in scheme implementation.

Such involvement has been circumvented in most cases by (a) the top-down method of scheme implementation characteristic of the implementing bureaucracy, especially the Forest Department; and (b) the hierarchical socioeconomic structures of the communities in which the schemes are located. We have seen that the causes for project failure lie not in the antagonism between people and trees, but in the antagonism and differential interests between people and people: between the forestry officials and tribal communities; between different class and kinship groups in the village, and so on. Successful projects have emerged precisely where the material basis for such antagonism (especially in terms of land ownership patterns) has either been eroded, say 
through a radical agrarian reform programme, or has not existed historically to the same extent (say, among more egalitarian hill communities).

In the very recent period in India there has been some move to incorporate the concerns of the poor and landless in forestry schemes, such as the allotment of plots of government-owned degraded forest land or wasteland to small numbers of landless families for planting trees, as in West Bengal and Madhya Pradesh. These families do not have ownership rights to the land but have usufructuary rights to the trees they plant, and seedlings and wages (or a stipend) are given in the initial period. In a few instances, groups of women have also been given wastelands for growing herbs. Mining, too, has been stopped in several areas to prevent further environmental degradation. However, in most cases, these steps are the fruits of a concerted struggle by and pressure from local nongovernment activist groups; and at best, these measures remain concessions, and deviations from the national picture.

Alongside these measures several States are proposing to lease out large tracts of degraded forest land to paper mills for afforestation, to provide pulp, and Karnataka has already taken a lead by leasing out 30,000 ha to the Mysore Paper Mills [CSE 1985:72-9]. At the national level, undeniably, the thrust of forest policy and implementation in India remains orientated to commercial needs. And this thrust is inseparable from the country's overall development strategy which defines the priorities between sectors, products, and technologies used for producing these products (with their associated implications for sources and levels of energy use).

The questions that then arise are: how can this development strategy be altered to take account of environmental concerns in general and the needs of the rural poor in particular? What would be the economic trade-offs of alternative strategies for the country as a whole, and for different classes and social groups within it? What would be the political constraints and feasibilities of alternative paths? These are questions that clearly have no easy answers, but it is imperative to probe them. So far they have not been addressed explicitly by planners or even by most activist groups in South Asia. Hence, on the one hand schemes are ostensibly being instituted to alleviate the firewood crisis facing the poor; on the other hand the existing plan priorities, development policies and their implementation are accentuating the crisis. We encounter once again the familiar paradox.

\section{References}

Agarwal, Anil, 1983, 'In the Forests of Forgetfulness', The Illustrated Weekly of India, Bombay, November 13-19

-and Priya Deshingkar, 1983, 'Headloaders: hunger for firewood-I', CSE Repor $/$ No. 118, Centre for Science and Environment, Delhi
Agarwal, Bina, 1986a, Cold Hearths and Barren Slopes: The Woodfuel Crisis in the Third World, Zed Books, London, and Allied Publishers, India

$-1986 \mathrm{~b}$, 'Women, property and agricultural growth in India', Journal of Peasanı Srudies, vol 13 no 4

Bahuguna, S., 1984, 'Women's non-violent power in the Chipko Movement' in Madhu Kishwar and Ruth Vanita, (eds.), In Search of Answers: Indian Women's Voices from Manushi, Zed Books, London

Bajracharya, Deepak, 1983, 'Deforestation and the food/fuel content: historico-political perspectives from Nepal', Working Paper, Resource Systems Institute, East-West Centre, Honolulu

Bandhyopadhya, Jayanto, 1981, 'Beyond the firewood march', Financial Express, September 1-2, India

Bapat, Shailaja, 1983, 'It lacks vitality', The Economic Times, India, August 6

Bhaduri, T. and V. Surin, 1980, 'Community forestry and women headloaders' in Comntunity Foresiry and People's Participation - Seminar Report, Ranchi Consortium for Community Forestry, November 20-22

BRAC, 1980, The Ner: Power Structure in Ten Villages, Bangladesh Rural Advancement Committee, Dhaka

Briscoe, John, 1979, 'Energy use and social structure in a Bangladeshi village', Populaion and Developmenı Revieu', vol 5 no 4, December

Cernea, Michael, 1981, 'Land tenure systems and social implications of Forestry Development Programmes', World Bank Sraff Working Paper no 452, April

Chand, Malini and Rekha Bezboruah, 1980, 'Employment opportunities for women in forestry' in Community Forestry and People's Participation - Seminar Report, Ranchi Consortium for Community Forestry, November 20-22

CSE, 1985, The State of India's Environment 1984-85: The Second Cirizen's Report, Centre for Science and Environment, New Delhi

Desai, Ashok V., 1980, India's Energy Economy: Facts and their Interpreiation, Economic Intelligence Services, Centre for Monitoring Indian Economy, Bombay, February

D'Monte, Darryl, 1982, 'Pine for the Forest?', The Hindustan Times, January 4

Dogra, Bharat, 1984, Forests and People, Bharat Dogra, A-2/184, Janakpuri, New Delhi

Eckholm, Erik P., 1975, 'The other energy crisis', World Warch Paper no 1, World Watch Institute, USA

Guha, Ramachandra, 1983, 'Forestry in British and PostBritish India - A Historical Analysis', Economic and Polinical Weekly, October 29 
Hughart, David, 1979, 'Prospects for traditional and nonconventional energy sources in developing countries', World Bank Staff Working Paper no 346, World Bank, Washington D.C., July

Howes, Mick and M. A. Jabbar, 1986, 'Rural Fuel Shortages in Bangladesh: the evidence from four villages, Discussion Paper 213, IDS, Sussex

Indian Express, 1983, 'Tribals hostile to social forestry', July 10 , India

Islam, M. N., 1980, Problems and Prospects of Biogas Technology as a Mechanism for Rural Development: Study of a Pilot Area of Bangladesh, Final Report prepared for the IDRC, Ottawa

ITES, 1981, Rural Energy Consumption in Southern India, Institute of Techno-Economic Studies, Madras

Jain, Shobhita, 1984, 'Women and people's ecological movement: a case study of women's role in the Chipko Movement in Uttar Pradesh', Economic and Political Weekly, vol 19 no 41 , October 13

Jha, P. Shankar, 1983, 'Outlines of a forest policy: need to enlist the farmer', The Times of India, August 8

Joshi, Gopa, 1981, 'For people-oriented social forestry', Voluntary Action, India, January

Jodha, N. S., 1983, 'Market forces and erosion of common property resources', paper presented at the International Workshop on Agricultural Markets in the Semi-Arid Tropics, ICRISAT, Andhra Pradesh, October

-1986, 'Common property resources and rural poor', Economic and Political Weekly, vol 21 no 27, July 5

Makhijani, A., 1979, 'Economics and sociology of alternative energy sources', paper presented at the Environment and Development Regional Seminar on Alternative Patterns of Development and Life Style in Asia and the Pacific, ESCAP and UNEP, Bangkok, August 14-18

Nagbrahman, D. and S. Sambrani, 1983, 'Women's Drudgery in Firewood Collection', Economic and Political Weekly', January $1-8$

Nath, D., 1968, Of Logs and Men, Committee on Case Studies, Indian Institute of Public Administration, New Delhi
NCAER, 1981, Report on Rural Energy Consumption in Northern India, Environment Research Committee, National Council of Applied Economic Research, New Delhi

Ninan, S., 1983, 'Protecting the Forester', Indian Express, November 2

Novak, K. and A. Polycarpau, 1969, 'Sociological problems and Asian Forestry', Unasylva, FAO, vol 23(3) no 94

Poulsen, Gunnar, 1978, Man and Trees in Tropical Africa, Publicalion no 101c, IDRC, Ottawa

Ravindranath, N. H., et al., 1978, The Design of a Rural Energy Centre for Pura Village, Part I, Its Present Patlern of Energy Consumption, ASTRA, Indian Institute of Science, Bangalore

Romm, Jeff, 1979, 'Local organisations for managing natural resources: the distribution of economic incentives and social shares', (mimeo), Ford Foundation, Delhi

Roy, S., 1980, 'Experiences in Community Forestry, Behro Project in Bihar', in (eds.) R. N. Tewari and O. A. Mascerenhas, Community Foresty' Management for Rural Development, Natraj Publishers, Dehradun, India

Sarin, S., 1980, 'Experiences in Community Forestry: Madhya Pradesh' in Community Foresiry Management for Rural Developmenı (op. cit.)

Swaminathan, S., 1982a, 'Environment: Tree versus Man', India International Center Quarterly', vol 9 nos 3 and 4

$-1982 b$, 'The Green Revolution bound up in red tape', Report no 82, Center for Science and Environment, New Delhi

UTTAN, 1983, 'A Question - Why is Social Forestry not "Social"?" paper presented at the Ford Foundation Workshop on Social Forestry and Voluntary Agencies, Badhkal Lake, Haryana, April 13-15

World Bank, 1983a, Gujarat Community Forestry Project Mid-Term Review Mission Report, World Bank, India

- 1983b, Utiar Pradesh Social Forestry Project - Mid-Term Review Mission Report, World Bank, India 